SOCIAL RESEARCH REPORTS

ISSN: 2066-6861 (print), ISSN: 2067-5941 (electronic)

\title{
RETURN TO SOCIAL CAPITAL: CASE STUDY
}

\section{Catalin-George FEDOR}

Social Research Reports, 2019, Vol. 11, Issue 3, pp. 124-139

The online version of this article can be found at:

www. researchreports.ro

\section{https://doi.org/10.33788/srr11.3.9}

\section{Published by:}

Expert Projects Publishing House

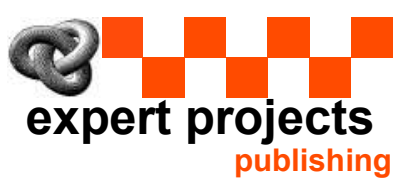

Covered by Index Copernicus International www.indexcopernicus.com

Directory of Open Access Journals www.doaj.org

On behalf of:

Center for Program and Social Development

Aditional services and information about Social Research Reports can be found at: www.researchreports.ro 


\title{
RETURN TO SOCIAL CAPITAL: CASE STUDY
}

\author{
Catalin-George FEDOR ${ }^{1}$
}

\begin{abstract}
In this paper we propose to reconsider the concept of social capital and to present the results of a study on how social identity is being built, a study conducted on the ground in an ethnic, confessional and cultural community in a period of post-communist transition. The research is a quantitative one. The results highlight the current practical value of the social capital concept, internalized and manifested differently by the different social groups belonging to the same communities. Equally, social capital is a vector of preserving local identity and the community can rely on it to shape its future.
\end{abstract}

Keywords: social capital, ethnic community, local identity, future perspective, community.

\section{Introduction}

Our study focuses on the social capital of members of a community and the aim is to reveal the virtues of the social capital concept and the way people relate to him. The classic definition of social capital is given by Bourdieu (1986: 248249 ) as "the aggregate of the actual or potential resources which are linked to possession of a durable network of more or less institutionalized relationships of mutual acquaintance and recognition [...] which provides each of its members with the backing of the collectively-owned capital, a «credential» which entitles them to credit, in the various senses of the word". From our point of view, social capital "refers to the relations between people, the so-called social networks, rules of reciprocity, and generalized trust among people. Social capital is very close to civic virtue, a virtue that calls for mutual social relations. Regardless of the different aspects of its definition, a common tendency is preserved by the idea of resource available to the individual or to a social formation" (Fedor, 2019: 65). As we mentioned in a previous paper (Fedor, 2014), we generally perceive local community as a more or less homogenous group made up of people who assert a certain form of identity given by the consciousness of a past or a common

${ }^{1}$ Romanian Academy, Iaşi, ROMANIA. Email: cgfedor@yahoo.com 
origin. This identity (often assimilated to the local specificity) is equally built by members of that community. This fact that we can call consciousness is grounded on some relatively objective criteria, such as the place, institutions or cultural traits containing aspirations and joint projects. It results that community membership seen as consciousness can be defined by the meaning given by the individual to the criteria listed above. In this regard, we propose to see if the members of a community consider the social capital as a criterion of belonging to the community.

\section{Theoretical aspects}

The social capital concept is versatile and prolific, being criticized precisely for this reason. A first attempt to systematize the meanings of the concept was made in the above mentioned work (Fedor, 2019: 66-70). Further on, we shall present its main meanings, fields of application, as well as results from various field investigations. We will present some extremely varied research results from many perspectives and geographical areas. Portes (2000) drew attention to the fact that the popularity of the social capital concept has been accompanied by increasing controversy over its meaning and its concrete effects. Within a wider context, it is possible that much of its alleged benefits are misleading, despite the current popularity of the concept, which may have implications for both theory and policies based on it and addressed to communities. Social capital was presented as a remedy for society, despite some unresolved arguments about what is right, how it is created, and why it is declining in the West, according to Lovell (2009). The major critique of the concept lies in the dual quality of social capital as a means of analysis and as a political objective. Poder (2011) also draws our attention that although studies of social capital emphasize its place in the economy and there is a burgeoning literature in this regard, we must take into account the wider social context to highlight it correctly.

Starting from a detailed case study of a political and cultural organization, Perreault (2003) examines the formation of social capital (defined as the rules of trust and reciprocity that are integrated into social relations) and the ways in which rural organizations can have access to rights and resources. In this respect, the author points out that the formation of social capital must be seen in the context of symbolic systems or cultural capital. The social capital concept provides a valuable conceptual framework for analysing multi-scale processes of environmental management, rural development and resource conflicts that have led to many social movements in rural areas in different regions of the world. Coffé (2009) notes that a more pronounced heterogeneity of the community is associated with lower levels of social capital. The study was carried out on a large number of municipalities, and the number of parties present on the local political scene was used as a more comprehensive measure of community heterogeneity.

Another point is made by Upton (2008) who makes a longitudinal assessment of trust, collective action and cooperation between people in a society facing a period of transition. The results highlight the important catalytic effect of external interventions in overcoming the lack of trust and in promoting a formal collective action, but only in the context of a specific conjuncture of circumstances, which also 
highlights the fragility of social capital. The social capital concept is increasingly used in the field of community development and social economy (Fedor, 2016a). The main benefit for the community is the expected change in behaviour, attitude and identity (Fedor, 2016b). Social capital can also be used as a means of fighting poverty. Dhesi (2000) shows that there is an increase in the recognition of social capital as a resource that can facilitate and constrain social action. Following his analysis, the author points out those macro-structural changes have an impact on social capital and its role in community development, and formal institutions, if in conflict with informal institutions, can severely constrain collective action. Mubangizi (2003) analyses the importance of social capital to communities living in rural areas and their potential for improving living conditions in rural areas. The author believes that this important form of capital can be fully used to accelerate the fight against poverty through community economic development and promotes sustainable livelihoods. There is considerable evidence in the specialised literature that attests the way in which social capital contributes to poverty reduction, but emphasizing the way in which development actors can strengthen productive social capital for poor people remains limited, Seferiadis, Cummings et al. (2017) consider. The authors are pushing for this deadlock to create a dynamic framework that aims to strengthen the social capital of communities faced with poverty, which would facilitate the development of the community.

Making reference to the role of the individual and the community in forming social capital, Godoy (2007) notes the positive and significant correlation between the contribution of private investment and the increase of the social capital of the community. Literature on social capital and entrepreneurship often explores the individual benefits of social capital, such as the role of personal networks in promoting self-employment. Iyer, Kitson and Toh (2005) question the role of the region in assessing social capital. They analyse the relations between social capital, economic performance and regional development, and highlight the complexity and variability of these relations in space. Contrary to the conventional macroeconomic approach to the use of social capital ratios in formal growth models, the authors believe that a more nuanced analysis is needed to assess the impact of social capital on the region. In addition, they indicate the need to distinguish between local and non-local forms of social capital and conclude by suggesting that a future analysis of social capital will benefit from a specific regional approach to examine its evolution and impact. Oh, Lee and Bush (2014) believe that different types of social capital facilitate the creation of intra-regional or inter-institutional economic development partnerships because they reduce the transaction costs that can lead to the inefficiency of collective actions. Starting from the premise that previous studies focused on explaining the way in which collective action mechanisms lead to the creation of economic development partnerships, the authors create a typology that presents different dimensions of social capital and tests the effects of multidimensional social capital on various partnerships economic development. The results indicate that different dimensions of social capital contribute to the creation of economic development partnerships, regardless of the local boundaries.

Bebbington and Perreault (1999) attempt to develop a theoretical framework for the correlation of social capital with themes on sustainability, access to resources and livelihoods of communities. This framework concerns the sustainability of 
livelihoods and local economies in two dimensions. One consists of models of access to the produced human, natural and social capital. The other takes into account the role of social capital formation at different geographic scales in order to facilitate the access of the population (especially rural) to other forms of capital, both directly and through the involvement of other civil society actors. Social capital is essential for the development of knowledge-based economy and society. Understanding this has to be accompanied by a social balance to ensure cohesion, equity and poverty reduction, according to Lukkarinen (2005). The ultimate goal would, in the author's view, be to reach the stage of social equity, and for this, better cooperation between public authorities and social and economic actors is needed, which requires the essential dialogue between all actors and potential taxpayers. Asking if social capital is a necessary and sufficient condition for sustainable community development, Dale and Newman (2010) show that social capital is a prerequisite for sustainable community development as it strengthens links that increase access to non-community resources. However, capital itself is not always sufficient to support and develop local community initiatives, as it is often necessary to infuse economic and human capital. The authors raise the concept of a "social safety net" which, by extension, can play an essential role in local community development initiatives.

By correlating social capital with health, Scheffler and Brown (2008) present four mechanisms demonstrating their relationship. They consist in providing the community members with the necessary information, complying with social norms so that they have a real impact, strengthening health services and their accessibility in a community, and providing psychosocial support networks. In this respect, the authors define community social capital as the size and density of trust, cooperation, ties and associated activities in a particular population. Social capital plays an important role in population health programs as a component part of community development, Hyde-Peters and Simkiss (2016) consider; they show that the children's health curriculum in the community specifies that specialists should be aware of the literature on social capital and community development in terms of child health and well-being. Both social capital and community development are concepts unknown and ignored by most specialists in paediatrics, and filling this gap can be useful in paediatric practice for those working in the community and hospitals. Community development involves the creation of social and cohesion capital, to which social workers that labour in the community can make their contribution. Walker (2016) discusses the relation between the work of social assistance specialists and community development. In this respect, community development is seen as one of the tools used by social workers that labour in the community and is recognized as a qualified practice in social assistance education. On the other hand, community development is a discipline in itself, with its own values, theories and practical history, and is associated with other disciplines that have a wide scope of application, such as public health, sociology and others.

Returning to the connection between theory and practice, different authors have reconsidered and customized the social capital concept. Schmid (2003), for example, considers that capital forms are abstract constructs that dominate contemporary thinking. The very idea of human capital has emerged as a necessity to compensate for the lack of efficiency regarding the concept of physical capital 
in explaining the economic development very well. Social capital is seen as an important lever in economic development policy and in the development of private strategies. In the contemporary economy, social capital is identified by some people with norms and networks that increase trust, reciprocity and cooperation for the production of public goods. Critics, however, argue that this type of (social) capital is mainly of individualistic origin and provides a solid basis for subordinating labour through capital. Christoforou (2013) supports social concepts of social capital that relates to people's ability to share a sense of social obligation and shared identity and to pursue common strategies for public welfare. The author attempts to re-establish "social" in social capital through the concept of social incorporation, in which individuals engage freely in reflection processes, social mobilization and political debate to assess different values and objectives, often contradictory, in several collective activities. Levien (2015) argues that collective social capital theories cannot explain the way in which networks, norms, and trust interact in a process of economic change. For example, there are capitalist differences between community members who can earn money at the expense of other community members, undermining confidence in collective norms and actions. In this respect, the author concludes that this type of capital is most likely seen as an aspect of social inequality that prevents inclusive development. Starting from a study conducted on the ground, Migheli (2017) examines the interdependencies between social capital and particular social philosophies that necessarily involve the inclusion of an individual's existence in society. Social capital, seen as the sum of interpersonal relationships and civic participation of a person, has proven to be essential in promoting social and economic development. The strong link between the social philosophy of a broad community and social capital demonstrates their potential value for the socio-economic development of the populations involved.

Sheikh, Syed et al. (2009) wonder whether social capital measurement is an effective tool or it can be used as a standard tool for assessing community initiatives. The authors' conclusion is that the use of social capital indicators to investigate the impact of community initiatives is useful, leading to an integrated approach to socio-economic development implemented by organized communities, supported by cross-sectoral actions to improve the quality of life. Exploring the role of social capital in community development, Bhuiyan (2011) recognizes social capital as a useful resource that facilitates social interaction and promotes mutual support and co-operation, thus improving the participants' livelihoods by generating better income and better community governance. However, it is not right to generalize the virtues of social capital in all communities, regardless of their particularities. An important remark made by the author is the appropriateness of the theory to practical conditions, and in this respect, social capital provides better results if it is used in accordance with the local conditions of an individualized society.

Last but not least, Gittel, Ortega-Bustamante and Steffy (2000) elaborate on the role of community development organizations, which are, in their opinion, the main means of developing low-income areas and started to be examined to the degree to which they increase citizens' participation, civic capacity and stabilize and revitalize these areas by creating social capital. In terms of gender, the authors consider that women play a key role in community development and, 
in this respect; most women-led community development organizations define their community development efforts in general, increase community capacity and strengthen local democracy. In so far as women-led groups contribute differently to the development of social capital by increasing community participation and confidence and by creating community networks and civic actions, they are a model for community development efforts. The concept of social capital can also be related to charity. Graddy and Wang (2009) focus on the potential role of community social capital, bringing up the role of community foundations. They believe that the recent worldwide multiplication of community foundations presents new opportunities for social change based on community. By fulfilling this promise, community foundations support the charity support of their communities. Social capital can be measured by analysing various associations of individuals through voluntary activities and philanthropy, according to Jordan, Anil, and Munasib (2010), and local economic development can explain the variation in social capital.

\section{Methohology}

\section{Research methods}

Thus, we propose to carry out an evaluation of how social capital can be manifested in an ethnic, confessional and cultural community in a period of postcommunist transition. We conducted our research in Săbăoani, a rural community from Moldova, Romania.

\section{Quantitative research}

Starting from various forms of capital suggested by Bourdieu (1986), we used a simplified tool for capturing social representations of social capital of studied group. We used a four-item scale ("I get involved in solving problems of any kind in my community", "I know I can rely on my relationships (relatives, neighbours, acquaintances) to solve my problems", "I like to get religiously and voluntarily involved for the good of my fellow citizens" and "I trust local authorities and local authorities trust me").

\section{Short presentation of studied community}

The community we studied village is located at the Eastern border of the Iași County, on a superior plateau between the rivers Siret-Moldova, north of city of Roman. Most inhabitants based on their own declaration Romanians (95.73\%). For $4.21 \%$ of the population, the ethnic belonging is not known. Concerning religion, most inhabitants are Roman Catholics (93.61\%), with an Orthodox minority $(1.89 \%)$. For $4.23 \%$ of the population, religious belonging is not known. 


\section{Demographic data}

Sample distribution on grounds of gender status reveals that over half of the participants in our research, i.e. $58.5 \%$, are female and $41.5 \%$ are male. As concerns sample distribution based on age, most respondents were aged 30 to 64 $(82.3 \%)$. They were followed by elderly respondents (13.3\%). Only $4.4 \%$ of them had up to 29 years of age.

Sample distribution based on the latest graduated school shows that most respondents were high school graduates (32.2\%). The next category included respondents who claimed in our research that they completed 10 grades $(24.7 \%)$. College is the latest school graduated by $14.8 \%$ of respondents. $12.3 \%$ of respondents said that their latest graduated school was higher education. 9.9\% of the surveyed population only completed junior high school (5-8 grades). 3.7\% of them said that they only completed primary education (1-4 grades). The lowest share, i.e. $1.2 \%$, is represented by respondents with no education and by those with postgraduate studies respectively.

\section{Results and discussions}

Sample distribution based on the answers to the statement "I get involved in solving problems of any kind in my community"

According to this distribution, it can be noticed that the highest percentage, namely $36.9 \%$, represents respondents who claimed that they got little involved in solving problems of any kind in their community. It is important to point out that only $1.1 \%$ of the surveyed participants said that they got involved to a very large extent in solving problems of any kind in their community.

Table 1. "I get involved in solving problems of any kind in my community"

\begin{tabular}{|l|l|}
\hline Not at all & $20.7 \%$ \\
\hline To a small extent & $36.9 \%$ \\
\hline So-so & $31 \%$ \\
\hline To a great extent & $10.3 \%$ \\
\hline To a very great extent & $1.1 \%$ \\
\hline Total & $100.0 \%$ \\
\hline
\end{tabular}

Based on the distribution of the respondents' opinion regarding the statement "I get involved in solving problems of any kind in my community" and on gender status, we noticed that $19 \%$ of the respondents were female and said that they get involved to a small extent in solving problems of any kind in their community. In a descending order of percentages, they are followed by male respondents who 
stated in our survey that they get involved to a small extent when it comes to any problems that their community may have $(17.7 \%)$.

Table 2. "I get involved in solving problems of any kind in my community" and gender status

\begin{tabular}{|c|c|c|}
\hline \multirow{2}{*}{$\begin{array}{c}\text { I get involved in solving } \\
\text { problems } \\
\text { of } \begin{array}{c}\text { any kind in my } \\
\text { community }\end{array}\end{array}$} & Male & Female \\
\cline { 2 - 3 } & $5.1 \%$ & $15.2 \%$ \\
\hline Not at all & $17.7 \%$ & $19 \%$ \\
\hline To a small extent & $16.5 \%$ & $15.2 \%$ \\
\hline So-so & $2.5 \%$ & $8.9 \%$ \\
\hline To a great extent & -- & -- \\
\hline To a very great extent & & \\
\hline
\end{tabular}

After processing the data obtained from the questionnaire process, we found that $31 \%$ of the respondents were aged between 30 and 64 and have little involvement in solving the problems of any kind of their community. $1.1 \%$ of respondents who claim to be very involved in solving any problems of their community belong to the same age category (30-64 years).

Table 3. "I get involved in solving problems of any kind in my community" and age distribution

\begin{tabular}{|l|l|l|l|}
\hline \multirow{2}{*}{$\begin{array}{l}\text { I get involved in solving } \\
\text { problems of any kind } \\
\text { in my community }\end{array}$} & $0-29$ years & $30-64$ years & $65-X$ years \\
\cline { 2 - 4 } Not at all & $2.3 \%$ & $14.9 \%$ & $3.4 \%$ \\
\hline To a small extent & -- & $31 \%$ & $5.7 \%$ \\
\hline So-so & $1.1 \%$ & $25.3 \%$ & $4.6 \%$ \\
\hline To a great extent & $1.1 \%$ & $9.2 \%$ & -- \\
\hline To a very great extent & -- & $1.1 \%$ & -- \\
\hline
\end{tabular}

According to the data shown in table no. $4,10.3 \%$ of respondents completed high school education and did not get involved at all in solving problems of any kind of their community. The same percentage of respondents had the same level of education but they got involved to a small extent in any problems in their community. 
Table 4. "I get involved in solving problems of any kind in my community" and level of training

\begin{tabular}{|c|c|c|c|c|c|}
\hline \multirow{2}{*}{ Latest graduated school } & \multicolumn{5}{|c|}{ I get involved in solving problems of any kind in my community } \\
\cline { 2 - 6 } & Not at all & $\begin{array}{c}\text { To a small } \\
\text { extent }\end{array}$ & So-so & $\begin{array}{c}\text { To a great } \\
\text { extent }\end{array}$ & $\begin{array}{c}\text { To a very great } \\
\text { extent }\end{array}$ \\
\hline No education & - & $1.3 \%$ & - & - & - \\
\hline Primary school (1-4 grades) & $2.6 \%$ & - & $1.3 \%$ & - & - \\
\hline $\begin{array}{c}\text { Junior high school (5-8 } \\
\text { grades) }\end{array}$ & - & $6.4 \%$ & $3.8 \%$ & - & -- \\
\hline 10 grades & $3.8 \%$ & $6.4 \%$ & $9 \%$ & $3.8 \%$ & $1.3 \%$ \\
\hline High school & $10.3 \%$ & $10.3 \%$ & $9 \%$ & $1.3 \%$ & -- \\
\hline College & $2.6 \%$ & $7.7 \%$ & $2.6 \%$ & $2.6 \%$ & - \\
\hline University & -- & $2.6 \%$ & $6.4 \%$ & $3.8 \%$ & -- \\
\hline Postgraduate education & -- & -- & $1.3 \%$ & - & - \\
\hline
\end{tabular}

Sample distribution based on the answers to the statement "I know I can rely on my relationships (relatives, neighbours, acquaintances) to solve my problems"

Quantitative data analysis reveals that most respondents (28.4\%) answered so-so when they had to choose the answer to the statement: "I know I can rely on my relationships (relatives, neighbours, acquaintances) to solve my problems".

Table 5. "I know I can rely on my relationships (relatives, neighbours, acquaintances) to solve my problems"

\begin{tabular}{|c|c|}
\hline Not at all & $10.2 \%$ \\
\hline To a small extent & $23.9 \%$ \\
\hline So-so & $28.4 \%$ \\
\hline To a great extent & $22.7 \%$ \\
\hline To a very great extent & $14.8 \%$ \\
\hline Total & $100.0 \%$ \\
\hline
\end{tabular}

$10 \%$ of female respondents claimed that they can rely to a very large extent on their relationships (relatives, neighbours, acquaintances) in solving their problems. As far as the proportion of male respondents who said the same thing, it amounts to merely $3.8 \%$. By analyzing the data in table no. 6 one may also notice that there were also respondents who stated that, when they have problems, they cannot rely at all on their relationships (relatives, neighbours, acquaintances) - $6.3 \%$ are female and $3.8 \%$ are male. 
Table 6. "I know I can rely on my relationships (relatives, neighbours, acquaintances) to solve

\begin{tabular}{|c|c|c|}
\hline \multirow{2}{*}{$\begin{array}{l}\text { I know I can rely on my relationships } \\
\text { (relatives, neighbours, acquaintances) } \\
\text { to solve my problems }\end{array}$} & \multicolumn{2}{|c|}{ Respondent's sex } \\
\hline & Male & Female \\
\hline Not at all & $3.8 \%$ & $6.3 \%$ \\
\hline To a small extent & $8.8 \%$ & $12.5 \%$ \\
\hline So-so & $15 \%$ & $16.3 \%$ \\
\hline To a great extent & $10 \%$ & $13.8 \%$ \\
\hline To a very great extent & $3.8 \%$ & $10 \%$ \\
\hline
\end{tabular}

According to the sample distribution on the basis of the answers to the statement "I know I can rely on my relationships (relatives, neighbours, acquaintances) to solve my problems" and age, we noted that most respondents aged 30 to 64 answered so-so to the aforementioned statement.

Table 7. "I know I can rely on my relationships (relatives, neighbours,

\begin{tabular}{c|c|c|c|c|} 
acquaint & \multirow{2}{*}{$\begin{array}{c}\text { I know I can rely on my relationships } \\
\text { to solve my problems }\end{array}$} & $0-29$ years & $30-64$ years & $65-X$ years \\
\cline { 2 - 5 } & Not at all & -- & $9.1 \%$ & $1.1 \%$ \\
\hline To a small extent & $1.1 \%$ & $19.3 \%$ & $3.4 \%$ \\
\hline So-50 & -- & $22.7 \%$ & $5.7 \%$ \\
\hline To a great extent & $1.1 \%$ & $21.6 \%$ & - \\
\hline To a very great extent & $2.3 \%$ & $9.1 \%$ & $3.4 \%$ \\
\hline
\end{tabular}

According to the data gathered about the latest graduated school, only $1.3 \%$ of respondents who completed postgraduate education cannot rely at all on their relationships when they have problems.

Table 8. "I know I can rely on my relationships (relatives, neighbours, acquaintances) to solve my problems" and level of training

\begin{tabular}{|c|c|c|c|c|c|}
\hline \multirow{2}{*}{ Latest graduated school } & \multicolumn{5}{|c|}{ I know I can rely on my relationships (relatives, neighbours, acquaintances) to } \\
& \multicolumn{5}{|c|}{ solve my problems } \\
\cline { 2 - 6 } & Not at all & $\begin{array}{c}\text { To a small } \\
\text { extent }\end{array}$ & So-so & $\begin{array}{c}\text { To a great } \\
\text { extent }\end{array}$ & $\begin{array}{c}\text { To a very great } \\
\text { extent }\end{array}$ \\
\hline No education & -- & $1.3 \%$ & - & -- & -- \\
\hline Primary school (1-4 grades) & $1.3 \%$ & -- & $2.5 \%$ & -- & - \\
\hline $\begin{array}{c}\text { Junior high school (5-8 } \\
\text { grades) }\end{array}$ & -- & $3.8 \%$ & $3.8 \%$ & -- & $2.5 \%$ \\
\hline 10 grades & - & $6.3 \%$ & $7.6 \%$ & $8.9 \%$ & $1.3 \%$ \\
\hline High school & $3.8 \%$ & $10.1 \%$ & $7.6 \%$ & $2.5 \%$ & $7.6 \%$ \\
\hline College & $1.3 \%$ & $2.5 \%$ & $3.8 \%$ & $6.3 \%$ & $1.3 \%$ \\
\hline University & $2.5 \%$ & $1.3 \%$ & $1.3 \%$ & $5.1 \%$ & $2.5 \%$ \\
\hline Postgraduate education & $1.3 \%$ & -- & - & -- & - \\
\hline
\end{tabular}


Sample distribution based on the answers to the statement "I like to get religiously and voluntarily involved for the good of my fellow citizens"

Based on sample distribution according to the answers to the statement "I like to get religiously and voluntarily involved for the good of my fellow citizens", more than $40 \%$ of the respondents' answers support this statement to a large extent. The lowest share of subjects said that they did not like to get religiously and voluntarily involved for the good of their fellow citizens.

Table 9. "I like to get religiously and voluntarily involved for the good of my fellow citizens"

\begin{tabular}{|l|r|}
\hline Not at all & $\mathbf{4 . 5} \%$ \\
\hline To a small extent & $18 \%$ \\
\hline So-so & $21.3 \%$ \\
\hline To a great extent & $42.7 \%$ \\
\hline To a very great extent & $13.5 \%$ \\
\hline Total & $\mathbf{1 0 0 . 0} \%$ \\
\hline
\end{tabular}

Based on the data collected and shown in table no. 10, one may notice similar percentages, i.e. $6.2 \%$, of respondents who declared that they like to get religiously and voluntarily involved to a very great extent for the good of their fellow citizens and are male, of female respondents who stated the same thing. The lowest shares, i.e. $2.5 \%$, were noticed among both male and female respondents who did not like at all to get religiously and voluntarily involved for the good of their fellow citizens.

Table 10. "I like to get religiously and voluntarily involved for the good of my fellow citizens" and gender status

\begin{tabular}{|c|c|c|}
\hline \multirow{2}{*}{$\begin{array}{c}\text { I like to get religiously and } \\
\text { voluntarily involved for the good } \\
\text { of my fellow citizens }\end{array}$} & Male & Respondent's sex \\
\cline { 2 - 3 } & $2.5 \%$ & $2.5 \%$ \\
\hline Not at all & $3.7 \%$ & $11.1 \%$ \\
\hline To a small extent & $8.6 \%$ & $12.3 \%$ \\
\hline So-so & $21 \%$ & $25.9 \%$ \\
\hline To a great extent & $6.2 \%$ & $6.2 \%$ \\
\hline To a very great extent & & \\
\hline
\end{tabular}

A share of $12.4 \%$ represents survey participants aged 30 to 64 who said that they are very pleased to get religiously and voluntarily involved for the good of their fellow citizens. It is important to note that there are no young respondents (0-29 years) who said the same thing. Only $1.1 \%$ of respondents aged over 65 like to a very great extent to get religiously and voluntarily involved for the benefit of their fellow citizens. 
Table 11. "I like to get religiously and voluntarily involved for the good of my fellow citizens" and age distribution

\begin{tabular}{|c|c|c|c|}
\hline \multirow{2}{*}{$\begin{array}{c}\text { I like to get religiously and } \\
\text { voluntarily involved for the good } \\
\text { of my fellow citizens }\end{array}$} & $0-29$ years & $30-64$ years & 65 -X years \\
\cline { 2 - 4 } & -- & $4.5 \%$ & -- \\
\hline Not at all & -- & $12.4 \%$ & $5.6 \%$ \\
\hline To a small extent & $1.1 \%$ & $16.9 \%$ & $3.4 \%$ \\
\hline So-so & $3.4 \%$ & $36 \%$ & $3.4 \%$ \\
\hline To a great extent & - & $12.4 \%$ & $1.1 \%$ \\
\hline To a very great extent & & &
\end{tabular}

Only $1.3 \%$ of the people who completed postgraduate education claim that they are very pleased to get religiously and voluntarily involved for the benefit of their fellow citizens. The same share of respondents who did not go to school also greatly enjoys getting religiously and voluntarily involved for the benefit of their fellow citizens.

Table 12. "I like to get religiously and voluntarily involved for the good of my fellow citizens" and level of training

\begin{tabular}{|c|c|c|c|c|c|}
\hline \multirow{2}{*}{ Latest graduated school } & \multicolumn{5}{|c|}{$\begin{array}{l}\text { I like to get religiously and voluntarily involved for the good of my fellow } \\
\text { citizens }\end{array}$} \\
\hline & Not at all & $\begin{array}{c}\text { To a small } \\
\text { extent }\end{array}$ & So-so & $\begin{array}{c}\text { To a great } \\
\text { extent }\end{array}$ & $\begin{array}{l}\text { To a very } \\
\text { great extent }\end{array}$ \\
\hline No education & $\ldots$ & - & $\ldots$ & $1.3 \%$ & -. \\
\hline Primary school (1-4 grades) & - & $3.8 \%$ & $\ldots$ & - & - \\
\hline $\begin{array}{l}\text { Junior high school (5-8 } \\
\text { grades) }\end{array}$ & - & $2.5 \%$ & $5 \%$ & $2.5 \%$ & - \\
\hline 10 grades & - & $7.5 \%$ & $6.3 \%$ & $7.5 \%$ & $3.8 \%$ \\
\hline High school & $1.3 \%$ & $2.5 \%$ & $5 \%$ & $16.3 \%$ & $6.3 \%$ \\
\hline College & $2.5 \%$ & $1.3 \%$ & $2.5 \%$ & $7.5 \%$ & $1.3 \%$ \\
\hline University & - & - & $5 \%$ & $6.3 \%$ & $1.3 \%$ \\
\hline Postgraduate education & -- & - & - & - & $1.3 \%$ \\
\hline
\end{tabular}


Sample distribution based on the answers to the statement "I trust local authorities and local authorities trust me"

When the respondents were asked in the questionnaire to express their views on the statement: "I trust local authorities and local authorities trust me", most of them $(28.8 \%)$ were impartial and choose the so-so option. Statistical analysis revealed that the lowest share, i.e. $5.7 \%$, is that of surveyed participants, who said that they trust local authorities and that local authorities trust them to a very great extent.

Table 13. "I trust local authorities and local authorities trust me"

\begin{tabular}{|c|c|}
\hline Not at all & $\mathbf{1 8 . 4 \%}$ \\
\hline To a small extent & $19.5 \%$ \\
\hline So-so & $28.8 \%$ \\
\hline To a great extent & $27.6 \%$ \\
\hline To a very great extent & $5.7 \%$ \\
\hline Total & $100.0 \%$ \\
\hline
\end{tabular}

According to sample distribution based on the answers given to the statement "I trust local authorities and local authorities trust me" and gender status, an equal number of female and male respondents, i.e. $2.5 \%$, trust local authorities and local authorities trust them. According to the data collected by statistical processing and shown in table no. $14,17.7 \%$ of the questioned subjects were male and they were impartial when they had to express their opinion regarding the trust they have in local authorities and vice versa.

Table 14. "I trust local authorities and local authorities trust me" and gender status

\begin{tabular}{|c|c|c|}
\hline \multirow{2}{*}{$\begin{array}{c}\text { I trust local authorities } \\
\text { and local authorities trust me }\end{array}$} & Male & Respondent's sex \\
\cline { 2 - 3 } Not at all & $6.3 \%$ & $11.4 \%$ \\
\hline To a small extent & $6.3 \%$ & $15.2 \%$ \\
\hline So-so & $17.7 \%$ & $12.7 \%$ \\
\hline To a great extent & $8.9 \%$ & $16.5 \%$ \\
\hline To a very great extent & $2.5 \%$ & $2.5 \%$ \\
\hline
\end{tabular}

According to the results collected further to sample distribution based on the answers given to the statement "I trust local authorities and local authorities trust me" and age; only respondents aged 30 to 64 and those over the age of 65 declared that they trusted local authorities to a great extent and local authorities trust them. 
SOCIAL RESEARCH REPORTS - VOLUME 11, ISSUE 3 - NOVEMBER 2019

Table 15. "I trust local authorities and local authorities trust me" and age distribution

\begin{tabular}{|c|c|c|c|}
\hline \multirow{2}{*}{$\begin{array}{c}\text { I trust local authorities and } \\
\text { local authorities trust me }\end{array}$} & \multicolumn{3}{|c|}{ Age groups } \\
\cline { 2 - 4 } & $0-29$ years & $30-64$ years & $65-X$ years \\
\hline Not at all & $1.1 \%$ & $14.9 \%$ & $2.3 \%$ \\
\hline To a small extent & -- & $16.1 \%$ & $3.4 \%$ \\
\hline So-so & $2.3 \%$ & $25.3 \%$ & $1.1 \%$ \\
\hline To a great extent & $1.1 \%$ & $20.7 \%$ & $5.7 \%$ \\
\hline To a very great extent & -- & $4.6 \%$ & $1.1 \%$ \\
\hline
\end{tabular}

$1.3 \%$ of respondents claimed in their questionnaires that they did not go to school and trusted local authorities to a great extent and also thought that local authorities trusted them to the same extent.

Table 16. "I trust local authorities and local authorities trust me" and level of training

\begin{tabular}{|c|c|c|c|c|c|}
\hline \multirow{2}{*}{ Latest graduated school } & \multicolumn{5}{|c|}{ Itrust local authorities and local authorities trust me } \\
\cline { 2 - 6 } & Not at all & $\begin{array}{c}\text { To a small } \\
\text { extent }\end{array}$ & So-so & $\begin{array}{c}\text { To a great } \\
\text { extent }\end{array}$ & $\begin{array}{c}\text { To a very } \\
\text { great extent }\end{array}$ \\
\hline No education & -- & -- & -- & $1.3 \%$ & -- \\
\hline Primary school (1-4 grades) & $1.3 \%$ & $1.3 \%$ & -- & $1.3 \%$ & -- \\
\hline $\begin{array}{c}\text { Junior high school (5-8 } \\
\text { grades) }\end{array}$ & - & $2.6 \%$ & $1.3 \%$ & $3.8 \%$ & $2.6 \%$ \\
\hline 10 grades & $3.8 \%$ & $3.8 \%$ & $9 \%$ & $6.4 \%$ & $1.3 \%$ \\
\hline High school & $9 \%$ & $6.4 \%$ & $3.8 \%$ & $9 \%$ & $2.6 \%$ \\
\hline College & -- & $3.8 \%$ & $9 \%$ & $2.6 \%$ & -- \\
\hline University & $3.8 \%$ & -- & $5.1 \%$ & $3.8 \%$ & -- \\
\hline Postgraduate education & -- & -- & $1.3 \%$ & -- & -- \\
\hline
\end{tabular}




\section{Conclusion}

On the whole of the investigated population we observe a higher capitalization of the social capital from 30-64 aged people, followed by the elderly people, and who have a minimum 10 grades education level. The situation is relatively equal for both genders. A low level of social capital valuation is signaled to the young population. A possible explanation lies in the confidence in one's own strengths characteristic of the young age. For a deeper nuance of the results, it is necessary to correlate them with results obtained in different other communities (cultural, ethnic, confessional, degree of development etc.). The social capital may be included in a comprehensive definition of community. The notion of community refers not only to the idea of locality and particular or social kinship networks. It also has many subjective meanings that people attach to the place itself, to the social relations that they are part of and to the social group that they relate to. In terms of such meanings, the community may be recognized by its own social capital. Social capital reveals its paradigmatic value and can be successfully used in the traditional communities analysis. It can also be used as a predictive indicator for the community future trajectory.

\section{References}

Bebbington, A., Perreault, T. (1999). Social Capital, Development, and Access to Resources in Highland Ecuador. Economic Geography, 75(4), 395-418.

Bhuiyan, S. H. (2011). Social Capital and Community Development: An Analysis of Two Cases from India and Bangladesh. Journal of Asian and African Studies, 46(6), 533-545.

Bourdieu, P. (1986). The Forms of Capital. In J. G. Richardson (Ed.), Handbook of Theory and Research for the Sociology of Education (241-258). New York: Greenwood Press.

Christoforou, A. (2013). On the identity of social capital and the social capital of identity. Cambridge Political Economy Society, 37(4), 719-736.

Coffé, H. (2009). Social Capital and Community Heterogeneity. Social Indicators Research, 91(2), 155-170.

Dhesi, A. S. (2000). Social capital and community development. Community Development Journal, 35(3), 199-214.

Fedor, C. (2014). Towards a Postmodern Approach of Ethnic Community. Postmodern Openings, 5(2), 71-80.

Fedor, C. (2016a). Social Economics and Community Identity. Journal of Social Economy, $6(1), 35-52$.

Fedor, C. (2016b). Local Specificity and Social Economy. Journal of Social Economy, $6(2), 16-28$. 
Fedor, C.G. (2019). Social Capital and Community Development: Case Study. Social Research Reports, 11(1), 65-77.

Gittel, M., Ortega-Bustamante, I., Steffy, T. (2000). Social Capital and Social Change. Women's Community Activism. Urban Affairs Review, 36(2), 123-147.

Godoy, R. et al. (2007). The Role of Community and Individuals in the Formation of Social Capital. Human Ecology, 35(6), 709-721.

Graddy, E., Wang, L. (2009). Community Foundation Development and Social Capital. Nonprofit and Voluntary Sector Quarterly, 38(3), 392-412.

Hyde-Peters, Z., Simkiss, D. (2016). Social capital and community development in child health. Paediatrics and Child Health, 26(5), 205-211.

Iyer, S., Kitson, M., Toh, B. (2005). Social capital, economic growth and regional development. Regional Studies, 39(8), 1015-1040.

Jordan, J. L., Anil, B., Munasib, A. (2010). Community Development and Local Social Capital. Journal of Agricultural and Applied Economics, 42(1), 143-159.

Levien, M. (2015). Social Capital as Obstacle to Development: Brokering Land, Norms, and Trust in Rural India. World Development, 74, 77-92.

Lovell, S. A. (2009). Social Capital: The Panacea for Community? Geography Compass, $3(2), 781-796$.

Lukkarinen, M. (2005). Community development, local economic development and the social economy. Community Development Journal, 40(4), 419-424.

Migheli, M. (2017). Ubuntu and social capital: a strong relationship and a possible instrument of socio-economic development. Cambridge Political Economy Society, 41(4), 1213-1235.

Mubangizi, B. C. (2003). Drawing on social capital for community economic development: Insights from a South African rural community. Community Development Journal, 38(2), 140-150.

Oh, Y., Lee, I. W., Blanchard Bush, C. (2014). The Role of Dynamic Social Capital on Economic Development Partnerships within and Across Communities. Economic Development Quarterly, 28(3), 230-243.

Perreault, T. (2003). Social Capital, Development, and Indigenous Politics In Ecuadorian Amazonia. Geographical Review, 93(3), 328-349.

Poder, T. G. (2011). What is Really Social Capital? A Critical Review. The American Sociologist, 42(4), 341-367.

Portes, A. (2000). The Two Meanings of Social Capital. Sociological Forum, 15(1), 1-12.

Scheffler, R. M., Brown, T. T. (2008). Social capital, economics, and health: new evidence. Health Economics, Policy and Law, 3(4),_321-331.

Schmid, A. (2003). Discussion: Social Capital as an Important Lever in Economic Development Policy and Private Strategy. American Journal of Agricultural Economics, 85(3), 716-719.

Seferiadis, A. A., Cummings, S. et al. (2017). A dynamic framework for strengthening women's social capital: strategies for community development in rural Bangladesh. Community Development Journal, 52(2), 1-20.

Sheikh, Syed et al. (2009). Measurement of social capital as an indicator of community-based initiatives (CBI) in the Islamic Republic of Iran. Journal of Health Organization and Management, 23(4), 429-441.

Upton, C. (2008). Social Capital, Collective Action and Group Formation: Developmental Trajectories in Post-socialist Mongolia. Human Ecology, 36(2), 175-188. 